\title{
10. Scales of Identification: The City, the Rural
}

The everyday geographies of the queer migrant women interviewed for this study are largely urban geographies. Most of the interviewees who had a choice lived in cities, and thus the everyday lives they described were predominantly urban. Their narratives for this reason tended to reproduce the myth of the gay metropolis, which constructs the city as the location of queer people and communities. As discussed earlier, this myth is a theory that travels globally. Some interviewees had explicitly (also) emigrated based on their preconceptions about gay life in the Western metropolis. From this perspective the Western metropolis signifies "the gay part so because of the tolerance and the liberalism of the country and the city, of that spirit and of that atmosphere which is very open and free" - this is how Maria Borkovic describes the city of her dreams, an amalgamation of Berlin, Amsterdam, and Barcelona. The vigor and reach of this imaginary is also manifest in the fact that many interviewees had initially not planned to come to Switzerland but had wanted to go to a more metropolitan area. Some women explicitly lamented the fact that Swiss cities do not classify as metropolises. Especially interviewees who experienced social exclusion in Switzerland viewed the discrepancy between the assumed openness and cosmopolitanism of the metropolis and the perceived small-mindedness of Swiss cities as an explanation for experiences of exclusion. At the same time, most interviewees had come to appreciate the small-town character of Swiss cities, pointing to advantages like low levels of environmental pollution, a more leisurely tempo, short travel distances, plentiful green spaces, and so on.

Interviewees generally strongly identified with the cities where they lived. The pictures they presented often featured themselves in their favorite spots within these urban landscapes (this boulevard, that café, this fountain, the house I live in), which they talked about with a great deal of affection. In contrast to the scale of the (Swiss) nation, which remained a vague concept with little palpable connection to everyday life, the city emerged as the most tangible scale of identification. This manifests in the picture of the self-designated "95 percent Cuban and five percent Basler" that Teresa Ruiz presents of herself, showing herself comfortably leaning against a banister on the shore of the Rhine with the Basel cathedral in the background. Both the picture and the accompanying narrative convey an air of comfort, familiarity, belonging, appropriation, affection: "Ich liebe Stadt Basel" - "I love the city of Basel." 
These perspectives on the urban strongly contrast with perspectives on, and experiences in, the rural as discussed in earlier chapters. Accounts such as Nour Saber's and Nara Agayeva and Ramiza Salakhova's largely portray the rural in negative terms, reiterating dominant discourses juxtaposing the gay metropolis in opposition to a backward homophobic rural. However, across accounts, views on the Swiss rural were more complicated. This ultimate chapter discusses more systematically how the women interviewed in this study perceive the rural; how these imaginaries become actualized in everyday life; and how these perceptions and actualizations reinforce or subvert dominant ideas about the rural and especially rural (homo)sexualities in Switzerland. The chapter approaches the rural from two distinct yet related perspectives: Chapters 10.1 and 10.2 engage with the rural as a place to live; Chapter 10.3 with imaginations of nature and natural landscapes.

The focus on the rural here inevitably catapults this chapter into the body of literature investigating rural sexualities. As discussed in Chapter 3.3, the discipline of geography itself has been instrumental in framing the rural as nothing more than a place that homosexuals strive to leave in order to join gay communities in the city (Aldrich 2004, D'Emilio 1989, Weston 1995). It was not until the mid- to late 1990s that the rural eventually became a designated object of interest in geographies of sexualities (Bell and Valentine 1995c, Gorman-Murray 2008, Knopp 2000, Knopp and Brown 2003, Kramer 1995, Valentine 1997, Wincapaw 2000). These queer studies of the rural have since worked to recover experiences of homosexual subjects who have grown up and/or live in rural areas, and have examined gay and lesbian utopic and dystopic imaginaries of the rural. While these perspectives have usefully complicated dominant views of the rural as intrinsically homophobic and have challenged prevailing dichotomizations of the city and the rural, they themselves have produced a fresh set of exclusions.

First, this predominantly Anglophone literature has largely concentrated on Western Anglophone contexts. These geographies document developments like the establishment of lesbian farms in the U.S. in the 1970s, a phenomenon which did not develop in other Western countries to the same extent. In this period a significant number of lesbians throughout the U.S. chose to move to the countryside, establishing communitybased, women-only farms. These projects were framed in terms of an escape from heteropatriarchal civilization to an essentially feminine nature (Bell and Valentine 1995c, Valentine 1997). Beyond this, queer geographers (again predominantly in the U.S., but also in the U.K.) have documented lesbian communities in small towns, which functioned, and continue to function, on the basis of similar ideas. As Larry Knopp and Michael Brown write, "[the lesbian population] has been focused much more on creating a distinctly nonmetropolitan lesbian identity and politics, one governed by an alternative set of values that are often explicitly antiurban and antimaterialistic" (Knopp and Brown 2003:417). In other words, homosexuals' perspective on nature and the rural have been found to be highly gendered, with women identified as lesbians creating different kinds of communities tied to ideas about living in, and with, nature more than men identified as gay.

Second, like queer geographies overall, queer geographies of the rural have neglected to direct attention to non-Western and transnational configurations of sexualities, and have largely ignored international migration. This is surprising, seeing that 
migration has been inextricably linked to studies of rural sexualities from the very start. However, in this literature, migration has almost exclusively been framed in terms of rural to urban migration and vice versa. Also, it has largely failed to address the ways in which the rural is not only sexualized but also racialized and ethnicized. This chapter contributes to the development of a more transnational and postcolonial perspective on geographies of the rural.

\subsection{Living in the Swiss Countryside: Ambivalent Rural Closets}

In terms of the rural as a place to live, the narratives of the women interviewed in this study tended to frame the rural as a site of racism, xenophobia, homophobia, and social control. These views are grounded as much in hegemonic imaginations of the rural as in personal experiences -indeed, the two are constitutive of each other. As discussed earlier, Nara Agayeva and Ramiza Salakhova's strict avoidance of their fellow villagers results from their adoption of stereotypical ideas about the rural dweller, which coincides with their personal experiences of homophobia among orthodox religious people in their home country. At the same time, their negative perception of the place they live is a consequence of the fact that the couple had originally planned to go to a Western metropolis. This renders it impossible for them to conceptualize their village in anything other than negative terms, as 'not the place we wanted to be.' Ironically, Nara Agayeva and Ramiza Salakhova's preemptive practice of avoidance and hiding reinforces the very imaginaries of the Swiss rural they are constrained by. As racialized rural queers, they might upset stereotypical ideas about the rural as orthodox and homophobic; but by choosing to - and being disciplined into - remaining invisible as queers, the dominant inscription remains in place.

The couple's lack of identification with their village also finds expression in the photos they contributed to the research. On a two-hour walk I took with them along the local creek and over open fields - a walk the couple had repeated countless times since coming to Switzerland - the women only instructed me to take one single picture: of the window of their small room in the local home for asylum seekers they had been relegated to live in for their first six months in Switzerland before they were moved into their own small apartment. ${ }^{1}$ This is mirrored in Nour Saber's photo selection. Nour Saber, too, is forced to live in a small town due to immigration procedure, where she feels like a prisonnière. Although she lacks the economic resources to leave town on a regular basis, her imaginary ${ }^{2}$ photo collection did not include a single shot of her town but consisted exclusively of pictures of her favorite spots in her favorite cities in Switzerland, such as her preferred cafés, music stores, and lake shore boulevards. The crucial common denominator of these urban places was that they were explicitly places Nour Saber had not frequented with her former partner. For Nour Saber the city specifically

The couple had not wanted to take pictures themselves but instead offered to take a walk with me and tell me what to take pictures of. 
represents the stage on which she attempts to reclaim her independent Self, as opposed to her town, which is actually her former partner's hometown, and which also signifies her lost life with her partner. These two examples show that negative perspectives on the rural are always multi-facetted and contingent on the specific biography, and grounded both in imaginaries of the rural as well as in personal experiences in rural places.

By contrast, there are also voluntary migrations from the urban to the rural, which complicate the image of the Swiss rural as a dwelling place. Jasmine Sieto at first appreciated the personal contact with the dwellers of a small Swiss town where she lived for the $\mathrm{du}$ ration of a one-year internship in the course of her professional training. As an Asian she stood out in this place: "I'm the only Asian that time- no joke. I am the only Asian in Grandson. The only one." At first she appreciated this exposure and extra attention, which, having recently arrived from an Asian metropolis, was new to her. However, after a while she began to experience this singularity as burdensome, and so she was eventually glad to return to the city: "You feel totally alone, so I mean where I'm now [in the city], I survive all this villagey that's- hey no way, no way back there. It's enough now." For Ariane Velusat, too, the village in which she had started her apprenticeship as a social worker was a welcome reprieve from the busy multi-generational family home she had left behind in urban Venezuela, and she especially enjoyed having a 'room of her own' in a quiet place. It is moreover in this small village that she met the young Argentinian woman who later became her partner. The story of this rural encounter undermines the hegemonic inscription of the Swiss rural as intrinsically 'Swiss'/white and heterosexual (which will be engaged with in the next sub-chapter).

In contrast to these often temporary stays in the country (Ariane Velusat and her partner later also moved to the city), there are also interviewees who have moved there for good. As discussed earlier, Efra Mahmoud felt very pressured and exposed by the omnipresence of discourses around homosexuality in her urban everyday life. Having developed, post-migration, an "appreciation of what [s] he saw as the freedom associated with the absence of both labels and shame" when growing up in urban Egypt (Knopp and Brown 2003:418), the desire had emerged to return to Egypt, where she could strictly confine her homosexuality to the private space of the bedroom within her family home. I wrest Larry Knopp and Michael Brown's analysis from its original context on purpose: In the quote above the authors refer to the U.S. rural as pitted against the "flâneurie and gay gazing" and the proliferation of sexual discourses in the city (Bell et al. 2002:95). It is this perceived shared 'absence of labels and shame' in urban Egypt and in Western rural areas against which Efra Mahmoud's move from Zürich to a house she and her partner have purchased in a small Swiss town must be understood. Conflating the perceived discursive formations around sexualities in the Swiss rural and her home city, Efra Mahmoud's move seeks to reconcile what she loves and misses about Egypt (a family home, the privacy of sexuality) with what she loves about Switzerland (the punctuality, the cleanliness, the comfort). As Knopp and Brown argue in their discussion of narratives of gay men who had grown up in a rural area but later moved to the city: 
Even while the city was viewed as a site of (in this case) gay identity, and small or nonmetropolitan environments were viewed as sites of something more unnamed, interviewees frequently actually associated gay identity with closetedness and associated unnamed same-sex desire in small and nonmetropolitan environments with freedom! (Knopp and Brown 2003:416)

For Efra Mahmoud, their new house and neighborhood represent the inconspicuous "normal" life she seeks, surrounded by middle class heterosexual nuclear family life. Our interview took place in the garden of their house, separated from the neighbors' only by a thin wooden panel. The neighbors were in their garden too, gearing up for a barbecue, and whenever I asked a question Efra Mahmoud felt uncomfortable answering, she nodded towards the wall suggestively to indicate her reluctance to speak in front of the neighbors (who she believes 'know' about the nature of her relationship although they have not been told explicitly). During our interview, the geography of her new home already served its designated function as a rural closet, shielding Efra Mahmoud from questions she was reluctant to answer.

Efra Mahmoud's attempt to materialize a space in which both labels ('homosexual' or 'lesbian') and shame are absent converses with David Bell and Gill Valentine's documentation of the lives of queer people living in (often very remote) rural areas:

A further issue that must be discussed here is that of identity and identification. Autobiographical accounts [...] show that many people who feel attracted to others of the same sex, and many who act on those feelings, often actively deny the label 'homosexual,' let alone 'gay' or 'lesbian.' In fact, due to the intense heteronormative pressures of rural life, many are married [...]. For some men and women, any kind of acknowledgement of their own same-sex activities, fantasies or attractions is unthinkable, rendering even the most sensitive program or helpline useless (and, of course, these people rarely if ever show up on any kind of surveys into sexual behavior). (Bell and Valentine 1995C:116)

Bell and Valentine draw on the Kinsey Report from 1948, in which Kinsey states that rural men, especially men working in homosocial contexts, such as cowboys or lumberjacks, live "on realities and a minimum of theory," breeding the attitude that "sex is sex, irrespective of the nature of the partner with whom the relation is had" (Kinsey 1948:457, quoted in Bell and Valentine 1995c:117). The authors find "living on a minimum of theory" to be resonant with the lives of many men and women engaging in same-sex relationships in rural areas, and it is exactly this connotation of the rural with the absence of the notion of sexual identity (and thus the absence of the social rejection accompanying dissident sexual identities) that appeals to Efra Mahmoud. Of course, the small town Efra Mahmoud moved to cannot be compared to the living conditions described by Kinsey. In their study on women in the rural canton of Graubünden, Christina Caprez and Eveline Y. Nay describe the Swiss context in general as one "in which sexuality in general and homosexuality in particular" have become ubiquitous public issues, and these discourses have also reached the rural areas in Switzerland (Caprez and Nay 2008:295). In other words, both labels and shame are present in even the 'remotest' places of the Swiss rural. Hence, while Swiss rural - or small-town - realities will likely render it im- 
possible for Efra Mahmoud to implement her ideal of a label and shame free life, within Switzerland her new dwelling place represents the closest she can get to what she desires.

Efra Mahmoud was not the only interviewee who was weary of the pervasive sexualization of discourses in urban Switzerland. As Barbara Wiegand states: "Ich finde [Sexualität] nicht so ein super Thema-jeder hat eine [Sexualität], irgendeine, und ich teile das einfach nicht die grassierende Sexualisierung, das ist etwas das mir extrem auf den Geist geht" - "I don't consider [sexuality] such a great topic- everyone has one [a sexuality], any one [sexuality], and I just don't share that, the rampant sexualization, that is something that really gets on my nerves." She too has moved from the city to the rural. However, Barbara Wiegand's motivation to move to a village in the mountains was grounded not only in her desire to escape the sexual discourses proliferating in the city but in a number of other reasons, too. These motivations, and the complex notion of the Swiss rural that emerges from her views on and experiences in her new rural dwelling place are the focus of the next sub-chapter.

\subsection{Grabbing the Bull by its Horns: The Rural as the Epitome of Switzerland}

When Barbara Wiegand went to look at an apartment in a remote mountain village situated in one of the 'original cantons' of Switzerland ("Urschweiz") - this village hereafter called $\mathrm{X}$ - she thought to herself, " $X$ ist etwa das Absurdeste gewesen wo ich mir je habe vorstellen können, ich habe gefunden das gehe ich ankucken, und so in etwa bin ich dort gelandet, vielleicht weil ich gefunden habe das probiere ich jetzt aus, da bleibe ich jetzt" - "X was about the most absurd thing I ever could have imagined, I thought I'll go have a look at it, and that's about how I ended up there, maybe because I thought I'll try this out now, now I'll stay here." ${ }^{3}$ She had not left the city completely voluntarily, but rather had, among other things, been driven out of it due to rapid gentrification and an attendant increase in rents; as an artist, she was exposed to these developments to an increased degree. However, reflecting on her decision to move to $\mathrm{X}$, she realizes that there had been other motivations for this decisive change in her life:

TB: Aber warum genau? Was hat so wie den Entscheid herbei geführt nachher ']a, hier will ich wohnen?'

BW: Ehm- (Pause) die Wohnung hat mir gefallen, es ist sehr billig gewesen und es hat-den Anschein auch etwas vom Abenteuer gehabt, das ist mirerst später so richtig bewusst gewesen, der Hausbesitzer hat mich eigentlich überführt weil am ersten Tag hat er gesagt 'Sie finden es da wohl wildromantisch' (lacht). Dann habe ich etwas aus der Wäsche herausgeschaut, es ist mir aber nichts daraufeingefallen, das ist meistens ein Zeichen, dass man etwas getroffen hat. Und dann habe ich gemerkt, das [ist ein (?)] kleines Dorf, und es hat sich dann auch bald erwiesen,

3 Urschweiz refers to the three Swiss cantons of Uri, Schwyz, and Unterwalden, which are geographically located in the heart of Switzerland, and which are commonly described as the first three cantons of what was later to become Switzerland. Barbara Wiegand's village is not named for reasons of anonymity. 
dass das für mich so ein-eigentlich so wie, ich habe gefunden also entweder kapiere ich jetzt die Schweiz oder ich kapiere es nie mehr, entweder renne ich mir jetzt den Kopf in dem [Name des Hausbergs] ein (beide lachen), oder ich schaffe es einmal darüber zu kommen oder darüber zu stehen, es hat denn-als es mir bewusster geworden ist habe ich das dann gerade gemerkt dass es sehr um das gegangen ist weil-also ich meine schweizerischer als im Herz der Schweiz in der Urschweiz (lacht) in einer Cemeinde von vierhundertfünfzig Leuten da habe ich gefunden das geht-also das ist jetzt die Steigerung oder? (beide lachen) von irgendwie ziemlich-allem. Und wenn du das nicht checkst, dannnn- (bricht ab)

TB: But why exactly? What, like, led to the decision 'Yes, I want to live here?'

BW: Ehm- (pause) I liked the apartment, it was very cheap and it had- an air of adventure, too, I only really realized this later, the house owner actually caught me because on the first day he said 'You probably think this is wildly romantic' (laughs). I was left with egg on my face, but I didn't know what to say, this is usually a sign that something has hit the mark. And then I realized, this [is a (?)] small village, and it also turned out soon, that this is for me- like, I found well either I figure Switzerland out now or I'll never figure it out ever, either I bash my head on [name of local mountain] now (both laugh) or I manage someday to get over it or be above such things, there is- when I noticed this I realized immediately that it was very much about this because-well I mean more Swiss than in the heart of Switzerland within the 'original cantons' (laughs) in a village with four hundred and fifty inhabitants there I thought- well this is it, you know? (both laugh) of just about like- everything. And if you don't get this, thennnnnn- (breaks off) -Barbara Wiegand

While the prospect of living in $\mathrm{X}$ promised a welcome reprieve from the financial pressures of the city and provoked a sense of adventure and romanticism, $\mathrm{X}$ also represented the epitome of Switzerland. Barbara Wiegand's complex positionality as a lesbian of color who grew up in an adoptive family has not allowed her to develop a sense of home in Switzerland, and X has become the emblem and materialization of everything that she has not been able to grasp about this country, providing her with a chance to 'grab the bull by its horns': "if you don't get this, thennnnn-." The Alps (and especially the 'original cantons') as the paradigmatic symbol for the white Swiss nation, and the smallscale organization of the social in the narrow Alpine valleys (in which, in Barbara Wiegand's view, the primal fear of what waits behind the next pass crucially shapes people's mindset), render $X$ the perfect locus to actively study and challenge her relationship to Switzerland.

Over the many years she has been living in X, Barbara Wiegand's relationship to the village has become complex and highly ambivalent and has defied any conclusive 'getting it.' At first she was regarded as some kind of "Wundertier" - a marvelous exotic animal. At the start she made a point of mingling with the locals, arguing with them at the regulars' table in the local tavern. She engaged in community life by working with children but later withdrew from these activities, too depressed to witness the village dying out due to lack of work, emigration, and suicides. She constantly oscillated between feeling included and excluded from the community, but a turning point was when she won an artists' scholarship. This was mentioned in the local newspaper, after 
which many villagers expressed their pride in her, with some even thanking her for living in the village.

Despite her marked ambivalence towards X, Barbara Wiegand refuses to frame the city as a better place for non-white homosexuals but instead points to urban dwellers' own kinds of narrow-mindedness. "Gibt es hinter Oerlikon eigentlich noch menschliche Wesen, die meiner Aufmerksamkeit würdig sind?" - "Are there are any human beings beyond Oerlikon [a suburb of Zürich] that are worthy of my attention?," she mimics her friends in the city, who hardly ever visit her in the mountains. "Ich sage jeweils das ist genau gleich weit oder?" - "I always say it's the exact same distance, isn't it?" she states, and makes fun of these same friends' tales about 'hopping' to New York, London, and so on, boasting their mobility, open-mindedness, and cosmopolitanism.

In X, Barbara Wiegand lives "very much in the closet," which has triggered discussions with partners when they visited. On the one hand, Barbara Wiegand appreciates the rural closet since "it gets on my nerves anyway" to show, and be shown, intimacy in public. Not only that"ich [und nicht die Partnerin] käme ja die Breitseite ab wenn jetzt wirklich jemand [im Dorf] findet das läge nicht drin" - "it would be me [and not her partner] who would get the broadside if someone [in the village] couldn't come to terms with it." At the same time, she assumes that people 'know.' She perceives her closeted yet - as she perceives - visible lesbianism to coagulate with her "Gemischtrassigkeit" - "mixed race" and her gender to produce the sometimes vehement and blatant hostilities she has been repeatedly exposed to in the village:

In X habe ich manchmal wirklich Angst gehabt. Also regelrecht ANCST (Pause). Und das ist aber denke ich etwas irrational Unterschwelliges gewesen, anderenteils richtig Angst zum Beispiel habe ich dann das letzte Jahr gehabt, das Asylgesetzgeschwafel rundherum, wirklich. [...] Ich habe Zeiten gehabt wo ich gedacht habe adoptiert bist du, ehm-rassisch gemischt bist und lesbisch bist du auch noch-schlimmer kann es nicht mehr kommen, also gerade so klassische Marginalisierungs- Lieblingssachen zusammengefallen sind habe ich manchmal wieder gefunden uaaaaah-. Weil das ist ja-das geht ja in das Rassistische rein so Lesben garso Schwarze Lesben ist das allerletzte, das ist mir auch in New York von Schwarzen Lesben mitgeteilt worden. Und ich hab gefunden ich hab von allem so ein Bitzeli, das darfja wohl nicht wahr sein. Und das verschränkt sich dann manchmal. Also völlig irrational halt.

I have sometimes been really afraid in X. Downright AFRAID (pauses). And this was I think something irrationally subliminal, on the other hand I was downright afraid for instance last year, with the whole asylum legislation drivel all around, really. [...] At times I thought you're adopted, ehm- racially mixed and on top of that you're lesbianit can't get worse, well these classical marginalization favorites coinciding l've been thinking uaaaaah-. Because that's- this blends into racism like lesbians- like Black lesbians that's the very last thing [imaginable], this I have also been told by Black lesbians in New York. And I thought I have a bit of all of that, this can't be true. And this intersects sometimes. Like totally irrationally.

-Barbara Wiegand

This reflection refers to the moment addressed in an earlier chapter, when Barbara Wiegand sits in the local pub with the "village idiot." Discussing the issue of asylum with 
him, she attempts to provoke her interlocutor into bringing to the surface prejudices against her that the villagers usually keep under the lid "Eine Bierflasche in die Hand drücken und dann geht's [los]" - "Thrust a bottle of beer into his hand and there he goes"). As the increasingly heated argument threatens to derail she concludes it with the question: "Du musst mir jetzt noch eins sagen: Muss ich von jetzt an Angst haben wenn ich dir im Dorf begegne wenns dunkel ist?" - "Tell me one more thing now: Do I have to be afraid from now on when I meet you in the village at night?" In situations like these, Barbara Wiegand feels a limit has been reached, and that she should make explicit her lesbianism and fight for her position openly.

In contrast to her sexuality, of which nobody in the village speaks openly, she is regularly confronted with her racial identity: "Die Leute können es nicht lassen [zu fragen woher ich komme]" - "People cannot refrain from asking [where I am from]." She also ascribes this to being "mixed race," which defies quick categorization and as such seems to trigger a particularly strong desire for clarification among her fellow villagers (but also among people in the city). At the same time, the villagers' perception of her as a person of color fluctuates wildly. Sometimes she feels she has become incorporated into the community ("ingemeindet") and has become invisible as "ihr' $N-$ " - 'their' n-" as opposed to all other ' $\mathrm{N}-\mathrm{s}$ '/Ausländer. ${ }^{4}$ This incorporation is, however, never conclusive but can become reversed at anyone's discretion:

Bei dieser ehm- Asylgesetzrevision ist es wieder soweit gewesen, dass ich aus meinem Haus komme-also meinem Haus wo ich drin wohne, und mich frägt die Nachbarin, so im Stil von 'Hast du schon immer solche Haare gehabt?' Dann habe ich gesagt ich wohne seit zehn Jahren neben dir und du fragst mich etwas dermassen-bin an der Decke geklebt, oder?

When this revision of the asylum legislation was coming up, it reached a point again that I come out of my house- well the house I live in, and the neighbor asks me like 'Have you always had hair like that?' Then I said I've been living next to you for ten years and you ask me such a completely- I went through the roof, you know?

-Barbara Wiegand

Dealing with the sense of being at the mercy of her fellow villagers' shifting perceptions remains one of the greatest challenges Barbara Wiegand faces in her everyday life in X, and she has developed a fine sense for these fluctuations: "Ich gehe einkaufen-wenn sie mir wieder anfangen so Fragen stellen denke ich irgendwas haben die Schweizer wieder-Ah! Ah da ist die Asylgesetzrevision, okay" - "I go shopping. When they start to ask questions like that again I think the Swiss have something going on again- Ah! Ah there's the revision of the asylum legislation coming up, got it." Racism in the village is sometimes also blatant. A Black woman who has also been living in the village for years was initially not allowed to work in the local nursing home because the clients there were afraid the color of her skin would "rub off" ("abfärben"), genuinely believing it was dirt. At the same time, it is when this racism comes to the surface that Barbara Wiegand has an opportunity to 'grab the bull by its horns' and openly discuss issues that in the city are not considered politically correct while persisting subliminally. What is more, she has observed that the 
'tolerant' people in the city, "die Weissen, die nicht Rassisten sind, NIEMALS begreifen, dass sie nach wie vor die Definitionsmacht beanspruchen" - "the whites who are not racist NEVER understand that they continue to have the power of definition."

Barbara Wiegand's (shifting) visibility as a lesbian and/or a person of color unsettles the implicitly white, heterosexual, and patriotic self-understanding of X's inhabitants, as well as the hegemonic inscriptions of the 'definitive' Swiss landscape surrounding it. Indeed, her experiences and reflections mirror James Baldwin's experiences as an African-American in the mountain village Leukerbad, which he elaborates on in his essay Stranger in a Village (Baldwin 1955), and which expose Leukerbad as a virulently colonial space which continually establishes itself as white in opposition to the racialized colonial Other. Barbara Wiegand's account furthermore converses with the work of Black visual artists who challenge dominant ways of looking at allegorical landscapes. Photographer Ingrid Pollard, for instance, portrays Black people in an English rural landscape. Her images of Black people posing in a stereotypically English countryside immediately exposes that these landscapes are implicitly associated with white bodies. As the Women and Geography Study Group writes in their discussion of Pollard's work, the images featuring Black female figures "perhaps point towards the fear of lone women, particularly Black women, within English hill-walking country: '...feeling I don't belong. Walks through leafy glades with a baseball bat by my side....” (Women and Geography Study Group 1997, quoting Pollard 1993:185). For Pollard, the baseball bat refers to the English countryside as a locus of killing (for instance shooting grouse or foxes), which unmasks this landscape as a locus where species that are not considered worthy of life are simply exterminated. Pollard's analysis is reflected in Barbara Wiegand's experiences and fears, as well as her lack of control over her visibility as a person of color and a lesbian.

To conclude: For Barbara Wiegand, X represents a highly ambivalent space where she oscillates between feeling incorporated into the community and exposed as a foreign body, which is contingent on her fellow villagers' shifting perspectives in terms of her race, sexuality, and gender. At the same time, it is exactly the blatancy of these recurring exclusions that enable her to observe and react to these attributions. In Barbara Wiegand's view, this renders it easier to address racism, sexism, and homophobia in $\mathrm{X}$ than in urban spaces, where these issues persist but remain more subliminal and hence impalpable. Her conscious choice to live in $\mathrm{X}$ and to proactively engage with her fellow villagers' perspectives on herself in itself shows that Barbara Wiegand's position in $\mathrm{X}$ is not that of a victim. Although repeatedly marginalized in the village based on being "mixed race," an artist, a woman, and a lesbian, she at the same time embodies the local intellectual and as such commands a sense of authority and local pride. Moreover, her reflective stance with regard to her positionality within the social fabric of $\mathrm{X}$ positions her as a sort of anthropologist studying her interlocutors' perspective on the world and on herself, providing a critical distance even in, or especially in, the worst moments of discrimination. 


\subsection{Rural Utopias}

In contrast to interviewees' ambivalent experiences as rural dwellers and the predominantly negative imaginaries they harbor of the Swiss rural as a place to live, nature and natural landscapes are (often exceedingly) positively regarded. Among the pictures provided for this research, many show natural landscapes of Switzerland, of the home country, or of other rural places. As in the case of family photos (see Chapter 6.1), these pictures were often not taken during the research period but were retrieved from digital archives, which highlights the importance of these spaces as imagined spaces in everyday life. Other pictures were taken explicitly for the research, on walks or bike rides that were part of a daily or weekly routine.

Pitted against the urban, narratives construct natural landscapes as a site of reprieve from the pressures of everyday life exerted by multiple forms of discrimination, stressful situations at work or in the family, separation from loved ones, and so on. For Leyla Haddad, one of the most important everyday spaces is the sky. It reminds her of the openness of the Lebanese landscape, but in the past especially also signified connection to her family in Lebanon, from whom she was forcibly separated as a child during the civil war in the 1970s and 1980s: "Eine Zeit lang als ich in der Schweiz gewesen bin und meine Eltern unten [im Libanon] gewesen sind habe ich einfach gewusst der Himmel ist so verbindend, kann ich in den Himmel schauen und sie, irgendwo verbindet das uns, oder?" - "For a time when I was in Switzerland and my parents were down there [in Lebanon] I just knew the sky is so connecting, I can look into the sky and so can they, somewhere this connects us, you know?" For her the sky is a source of calmness, which she continues to seek on her daily walks along the local river. Like Leyla Haddad, many interviewees describe regular walks or bike rides in a natural environment as an intrinsic and crucial part of their daily or weekly routines. For Leyla Haddad, Beatriz Krais, Charlotta Sembiring, Lorena Moreno, Jasmine Sieto, Ayesha Umar, Cristina Pérez, and Pilar Gómez, being in natural environments is an important moment of reflection and meditation, but more specifically it offers reprieve from a stressful everyday life marked by marginalization and social isolation. As one interviewee stated, "der Natur ist es egal ob ich eine dunkle Haut habe oder lesbisch bin" - "nature doesn't care whether I have brown skin or am lesbian." As a space perceived to be free of language, nature also represents a space free of 'labels' and judgment.

Natural environments are also visited in the context of other recreational activities, such as hiking or biking holidays, or when showing visiting family members around Switzerland. Often, interviewees have only 'discovered' outdoor activities in Switzerland, not having hiked or biked before migrating. Some hope to find the sense of connection they are denied in their workplace through outdoor groups (with little success, however). As the sheer quantity of images shown to me featuring natural landscapes taken on holidays testifies to, experiences in these natural landscapes play an exceedingly important role in interviewees' everyday lives as imagined spaces. As Laura Georg explains, for her the memory of a holiday at the seaside or a moment on a hike continues to critically determine how she fares in everyday life long after returning from the trip. And while many non-migrant and non-queer people will likely offer similar reflections, in the light of queer migrant women's experiences of exclusion from family, 
friendship, and partnership, nature and natural landscapes as sites of reprieve gain a specific importance.

\subsection{Conclusion}

Queer migrant women's perspectives on the rural confirm the findings of those critical geographers who have been challenging the popular binary which pits the gay city against the homophobic rural. Based on ethnographic studies of queer rural dwellers in Western countries, critical scholars instead suggest that the flows of queer people and ideas have to be understood as multidirectional, influencing both the urban and the rural in terms of the development of their cultures, subjectivities, and politics (Knopp and Brown 2003:417). While some biographical narratives generated in the context of this study reiterated the dominant discourse that constructs the rural as homophobic, other accounts upset this dominant dichotomy. These disruptions on the one hand find their expression in utopian imaginations of the rural and on the other arise from the accounts of those interviewees who have 'paradoxically' moved from the urban to the rural.

The examination of queer migrant women's perspectives on, and experiences in, rural areas in Switzerland expose that queer immigrant women are positioned in significantly different ways vis-à-vis the rural than non-immigrant lesbians. One such difference concerns migrant women's imaginative geographies of the rural and nature respectively. As existing research shows, for non-immigrant lesbians, natural landscapes often provide a surface for utopian, anti-urban inscriptions and as such signify a respite from homophobia and heteropatriarchy (Brown and Knopp 2003, Büchler 2003, Kramer 1995, Valentine 1997). By contrast, for queer migrant women nature specifically also signifies a space free of racism and xenophobia, from which nature emerges as a space devoid of the multiple exclusions and pressures they experience in different areas of their everyday life.

These notions of nature, which configure nature as a place to escape to rather than from, are contrasted by perspectives on rural areas as a place to live. Both in terms of the ideas the accounts convey about the rural as a dwelling place, as well as in terms of interviewees' personal experiences as rural dwellers, the accounts mostly reproduce the dominant discourse that pits a gay-friendly city against a homophobic rural. This perspective is particularly marked in accounts by interviewees who are condemned to live in the rural due to asylum or immigration procedures, and who mainly frame their rural experiences in terms of confinement and imprisonment.

There are, however, notable exceptions to this rule, represented by interviewees who have consciously moved to the countryside or to small towns. Their ambivalent or positive views on the rural defy a simplistic categorization of the rural as the locus of racism and homophobia. For these women, moving away from the city not only addressed their wish to be closer to nature but also held the promise of an everyday life removed from the perceived oversexualized discourses in the city and 'ghettoized' urban lesbian communities. At the same time, these accounts make clear that the option to materialize rural utopias by moving to the countryside is not available to queer migrant women in 
the same way as it is to white and/or non-immigrant lesbians. Christina Caprez and Eveline Y. Nay (2008) have documented such experiences by non-immigrant lesbians who have moved (back) to the rural canton of Graubünden. Like Barbara Wiegand, the lesbians Caprez and Nay interviewed were able to gain a certain social status and acceptance in their villages based on their work, for instance as pastors, farmers, or nurses. ${ }^{5}$ However, unlike Barbara Wiegand, "none have experienced open rejection" in their village (ibid:269-270, my translation). By contrast, as Barbara Wiegand's account demonstrates, queer migrant women's corporeal presence in the Swiss countryside deeply unsettles dominant imaginaries of Swiss rural life, which uncovers the implicit encoding of these landscapes as white and heterosexual.

Barbara Wiegand's presence disturbs dominant imaginations of the Swiss nation, even more so as the particular mountain region she chose to inhabit symbolizes the myth of the Swiss nation par excellence, whose history and topography frequently continues to be invoked in contestations of 'Swissness' and Swiss history in the political and public arena. Populist discourses in particular claim the Alps as a nature-given emblem for Swissness, and Alpine dwellers as the archetypes of the 'autochtonous' Swiss people. Essentialist views on the Alps and its inhabitants persist despite the fact that the social history of the Alps is chiefly characterized by flows of trade and migration, from which the Alps emerge as a space of transit, connection, and meeting-up rather than the popularly evoked enclosed space organized into clear-cut spatial and social segments 'naturally' determined by mountains and valleys, which are moreover perceived to 'naturally' determine how Alpine dwellers 'are' (close-mouthed, hardworking, righteous, male, white). A historical moment crystallizes the degree to which the Swiss nation becomes equated with the Alps: In World War II, the Swiss military's Reduit strategy envisioned a worst-case scenario in which the (densely populated) flatlands would simply be given up, while the government and the armed forces would entrench themselves in gargantuan bunkers blown into the (sparsely populated) Alps. Nationalisms figuring the Alps are moreover deeply rooted in colonial thought. Public discourses around the Swiss Himalaya expeditions from the 1950 s onwards, for example (which aimed at 'conquering' the world's highest mountains in first ascents in the name of the Swiss nation), expose the ways in which colonial masculinities and imaginations of mountains merged to produce Swiss national identity (Purtschert 2019). ${ }^{6}$ Migrant subjects inhabiting the deeply white space of the Alps hence pose a threat to populist imaginations of Swissness and the possibility to acquire a house with a garden or to start a farm" (Caprez and Nay 2008:268, my translation). Women typically migrated in couples, starting up a farm or acting as pastors in a community together. 'Newcomers' typically adapted more to the local 'culture,' that is, they did not display their sexual orientation in public, while the 'returnees' (who returned to Graubünden after living in the city) tended to put their foot down with a greater sense of ownership (ibid:271).

6 Doreen Massey effectively debunks the myth of the Alps as the purportedly solid bedrock of Swissness. Arguing from a geological perspective, she instead frames the Alps as "immigrant rocks" from Africa (Massey 2005). This is particularly ironic seeing that the people who insist on attaching Swissness to the Alps in deeply determinist ways tend to be the same people who use this very essentialized 'Swissness' to keep out (especially also 'African') immigrants. 
and Switzerland. As Barbara Wiegand's account testifies to, these disruptions result in (often open) racism. At the same time, in Barbara Wiegand's rejection based on race and ethnicity coagulate with suspicions about her sexuality raised by fellow villagers due to the obvious absence of a heteronormative way of life, although these assumptions mostly remain subliminal. In the Swiss countryside, queer non-white women hence represent 'doubly paradoxical' bodies, whose presence unmasks the heterosexuality and whiteness of the Swiss mountains.

By engaging with queer migrant women's views on and experiences in the rural, this chapter has started to address the gap created by the fact that to date queer geographies have rarely addressed the implications of international migration on configurations of rural sexualities. Beyond this, it was suggested that rural geographies and postcolonial/transnational studies of sexualities be placed in a more engaged conversation with each other. David Bell and Gill Valentine's concept of how some rural queers live on "a minimum of theory" not only resonates with Efra Mahmoud's account of living with her parents in Egypt without 'telling,' but also reflects other interviewees' narratives about growing up in their home countries without role models - no matter whether these contexts were rural or not (see Chapter 5.3). In other words, like scholars analyzing rural sexualities, scholars engaging with postcolonial/transnational sexualities have been grappling with the implications of the "label and shame" tied to dissident sexualities. Both bodies of research engage with center-margin settings and are reproductive of dichotomies between allegedly modern (the city, the West) and allegedly backward places (the rural, the Orient, the South), aligning modern places with the concept of (sexual) identity and backward places with pre-identitarian stages of sexualities. The danger of unproblematically reproducing this hierarchized binary is especially present when discussing accounts of migrants who have moved from the rural to the urban and/or from the Orient/South to the West, as here the pressure to retrospectively frame pre-migration sexualities as pre-identitarian and thus inferior to post-migration "I am here and I am queer" sexualities and sexual identities is particularly marked. In this context both queer geographers and anthropologists have called for framing rural/postcolonial same-sex sexualities and intimacies as non-identitarian instead of pre-identitarian in a refusal to reinstate developmentalist narratives (Dankwa 2021). Stripping alternative sexualities of such temporalities opens up the conceptual possibility for positively connoted or neutral unnamed same-sex intimacies and relationships embedded in a context marked by the absence of both label and shame. 